Education (ALE). Bonn: DVV. URL: https://www.dvvinternational.de/fileadmin/files/Inhalte_Bilder_und_Dokumente/Materialien/ Analysis/DVV_International_Analysis_Financing_Popular_ALE_Web2.pdf [in English].

Strategies for improving participation in and awareness of adult learning. (2012). European guide. Luxembourg: Publications Office of the European Union. DOI: $\quad 10.2766 / 26886 \quad ; \quad$ URL: https://www.ab.gov.tr/files/ardb/evt/1_avrupa_birligi/1_9_politikalar/1_9_4_ egitim_politikasi/ec_guide_adult_learning.pdf [in English].

The SDGS in action. URL: https://www.undp.org/sustainable-development-goals Transforming our world: the 2030 Agenda for Sustainable Development: A/RES/70/1. Resolution adopted by the General Assembly on 25 September 2015. URL: https://www.un.org/ga/ search/view_doc.asp?symbol=A/RES/70/1\&Lang=E [in English].

УДК 304.374

DOI: https://doi.org/10.35387/od.1(19).2021.36-51

Чаграк Наталія Іеорівна доктор педагогічних наук, дочент, профресор кафедри іноземних мов і країнознавства Прикарпатського національного університету імені Василя Стефраника
Chahrak Nataliya - Doctor of Science in Education, Associate Professor, Professor of the Department of Foreign Languages and Country Studies, Vasyl Stefanyk Precarpathian National University

ORCID iD: http://orcid.org/0000-0002-1583-2278

E-mail: natalya.chahrak@pnu.edu.ua

Жумбей Маріанна Михайлівна - кандидат педагогічних наук, доцент, доцент кафедри іноземних мов і країнознавства Прикарпатського національного університету імені Василя Стефраника
Zhumbei Marianna - Candidate of Pedagogical Sciences, Associate Professor, Associate Professor of the Department of Foreign Languages and Country Studies, Vasyl Stefanyk Precarpathian National University

ORCID iD: http://orcid.org/0000-0002-8883-4135

E-mail:marianna.zhumbei@pnu.edu.ua

\title{
ПСИХОЛОГІЧНІ ЗАСАДИ НАВЧАЛЬНОЇ ДІЯЛЬНОСТІ ЛЮДЕЙ ТРЕТЬОГО ВІКУ
}

Анотація. Традиційні стереотипи щодо старіння, старості й людей третього віку, які довгий час панували в суспільстві, зазнають змін. Це пов'язано з соціальними, економічними, технологічними та культурними фракторами. Однією з характерних ознак суспільного 
розвитку останніх п'ятдесяти років є старіння населення, особливо у розвинених країнах світу. За прогнозами ООН, тенденція старіння суспільств зберігатиметься упродовж наступних десятиліть. Наприкіниі $X X$ - на початку $X X I \mathrm{~cm}$. з'являється новий тип соціально-демографрічної групи «люди третього віку» («старші дорослі» - амер.; пізній зрілий вік) особи віком 55-74 років - більш освічені, здорові та фрінансово забезпечені. Вони значно активніші у соціальному й політичному аспектах, ніж попередні покоління старших людей, а майбутні генерації старших дорослих прагнутимуть постійного особистісного зростання, що інтенсифікує розширення освітніх програм та сервісу для цієї вікової групи.

Історично склалося, що галузь наукового знання, яка найбільшою мірою пов'язана з вивченням навчання як діяльності особисmocmi, - це психологія. Відповідно, освіта й навчання людей третього віку значною мірою грунтується на теоріях психології (біхевіоризму, когнітивізму, когнітивного конструктивізму та психології розвитку), які розглядали процес навчання як френомен особистості. Водночас у площині соиіокультурної психології, теорії активності й теорії пізнання наукові дослідження сфрормували розуміння навчальної діяльності як форми сочіальної участі. Навчальна діяльність - невід'ємна умова позитивного старіння в сучасному суспільстві. Людина, будучи соціально активною у період пізньої зрілості, відчуває свою потрібність та корисність і в такий спосіб підтримує свою емоційно-особистісну та пізнавальну сферу.

Ключові слова: люди третього віку; модель навчання; освіта людей третього віку; освітня геронтологія; особистісний розвиток; старші дорослі.

Chahrak Nataliya, Zhumbei Marianna

\section{PSYCHOLOGICAL FOUNDATIONS OF OLDER} ADULT EDUCATIONAL ACTIVITY

Abstract. Traditional stereotypes regarding aging, old age and older adults, which have long dominated in society, are changing. This is due to social, economic, technological and cultural factors. One of the characteristic features of the social development of the last fifty years is the population aging, especially in the developed countries. According to UN forecasts, the trend of population aging in most developed societies will continue over the next decades. In more developed countries, life expectancy is increasing, the birth rate is decreasing, and the social and financial support of the older adults is improving. In the late XXth - early XXI century, in the developed countries, a new type of socio-demographic group "older adult» appeared (persons aged 55-74 years). They are more educated, healthy and financially supported people. They are significantly more socially and politically active than previous generations of older people, and future generations of older adults tend to continue their personal growth. This situation intensifies the expansion of educational programs and services for this age group. Historically, the branch of 
scientific knowledge, which is most associated with the study of learning as an activity of a person, is psychology. Accordingly, the education and training of adults and older adults is largely based on the theories of psychology (behaviorism, cognitivism, cognitive constructivism and developmental psychology), which viewed the learning process as a personality phenomenon. At the same time, in the area of sociocultural psychology, the theory of activity and the theory of cognition, scientific research has shaped the understanding of learning as a form of social participation. Learning activities are an essential condition for positive aging in modern society. A person, being socially active in late adulthood, feels their need and usefulness and thus maintains their emotional, personal and cognitive sphere.

Key words: educational gerontology; learning models; older adults; older adult education; personal development.

Постановка проблеми, її актуальність. Старість - своєрідний віковий та психологічний період життя людини, який характеризується значними фізіологічними, психічними та психологічними змінами організму. Традиційно старіння сприймається як процес деградації і спаду життєвих функцій, однак все більше наукових досліджень доводять, що розвиток особистості відбувається і впродовж цього періоду, зокрема завдяки активності людини й набуттю нових знань та умінь, що $€$ необхідною умовою поліпшення якості життя у пізній зрілості. Дієвим способом адаптації осіб третього віку до життя в умовах стрімкого високотехнологічного розвитку суспільства, необхідності подальшої особистісної самореалізації, комунікації поколінь та збереження людського капіталу стає ціложиттєва освіта. В цьому контексті розвиваються ідеї активного і позитивного довголіття, змістовної освітньої та освітньо-дозвіллєвої діяльності людей у пізній зрілості, спрямованої на реалізацію інтелектуального, професійного та громадянського потенціалу осіб цієї вікової когорти. Освіта старших дорослих (людей третього віку), яка сфрормувалася на основі двох освітніх концепцій: освіти впродовж життя та освіти дорослих, - френомен відносно новий, унікальний з огляду на цільову групу, мету, форми і методи навчальної діяльності, проте він характеризується стрімким розвитком, особливо у Європі та Сполучених Штатах Америки, що зумовлено швидкими темпами демографрічного старіння населення.

Зазначимо, що до 70-х років минулого століття більшість теоретичних основ навчальної діяльності формуються у певному контексті. Тому розглянемо наукові напрями психології, що обґрунтовують важливість розвитку, принципи освіти людей третього віку, специфріку мотивації (старших дорослих - амер.). У США для означення цієї вікової групи послуговуються терміном «старші дорослі» («older adults»)) задля створення оптимального й ефрективного освітнього середовища для цільової аудиторії цієї вікової категорії.

Аналіз останніх досліджень і публікацій. У контексті нашого дослідження значний інтерес становлять праці науковців з проблем:
- освіти
впродовж життя:
$€$ Є. Браді
(E. Brady),
Р. Хавігурст 
(R. Havighurst), П. Шеа (P. Shea), М. Тідмарш (M. Tidmarsh), І. Товнсхенд (I. Townshend), Д. Трейбіг (D. Treybig) та ін.;

- освіти дорослих: Л. Лук'янова, О. Огієнко, Б. Брегман (B. Bregman), К. Кросс (K. Cross), М. Ноулз (M. Knowles) та ін.;

- освітніх потреб і навчальної мотивації дорослих: О. Аніщенко, O. Баніт, P. Кафрарелла (R. Caffarella), C. Мерріам (S. Merriam) та ін.;

- впливу демографічних факторів на розвиток концепції освіти упродовж життя: В. Коль (W. Cole), Д. Хapic (D. Harris), Д. Кейт (J. Keith), П. Ласлет (Р. Laslett), Г. Мак Класкі (H. McClasky) та iн.

Освітня геронтологія як напрям науково-педагогічного дослідження набула розвитку у працях зарубіжних вчених, зокрема:

- концептуальні засади освіти людей третього віку обґрунтовано у роботах C. Басса (S. Bass), П. Джарвіса (P. Jarvis), Р. Гарісона (R. Harrison), Ф. Гленденнинга (F. Glendenning), П. Ласлетта (P. Laslett), Г. Мак-Класки (H. McClusky), Д. Петерсона (D. Peterson) та ін.;

- моделі геронтологічної освіти та особливості навчання людей третього віку проаналізовано у працях М. Браді (M. Brady), Б. Грумбріджа (B. Groombridge), Р. Хімстри (R. Hiemstra), Д. Джеймса, Ф. Гібсона, Г. Мак Алі (D. James, F. Gibson, G. McAley) та ін;

- психологічні особливості людей третього віку (старших дорослих) вивчено у дослідженнях: О. Коваленко, Л. Реснік (L. Resnick), Д. Левін (J. Levine), С. Тіслей (S. Teasley) та ін.

В Україні спостерігаємо демографрічну ситуацію стрімкого старіння населення. А це, своєю чергою, призводить до того, що соціальнодемографрічна група - люди третього віку (старших дорослих) - значною мірою визначає напрям і темп суспільного розвитку України на тривалу перспективу. Відповідно виникає необхідність звернути увагу на вигоди економічного, політичного, соціального та культурного характеру, які дає суспільству освіта людей цієї вікової групи. Ступінь залучення цього сегмента населення в освітню діяльність суттєво визначає такі характеристики суспільного розвитку як рівень безробіття і соціального навантаження, здатність країни адаптовуватися до соціально-економічних та культурних змін, швидкість розвитку суспільства в соціально-економічному плані, рівень незалежності (фрінансової, функціональної, соціальної) осіб третього віку. Задля створення оптимальних умов та ефективних освітніх програм для старших дорослих важливо вивчити психологічні аспекти навчальної діяльності людей цієї вікової групи.

Мета статті: використовуючи методи аналізу, синтезу, порівняння та узагальнення, простежити розвиток наукових підходів до навчальної діяльності осіб третього віку в контексті основних напрямів психології; виявити особливості навчальної діяльності людей третього віку в аспекті їхнього особистісного розвитку.

Виклад основного матеріалу дослідження. Освіта і навчання людей третього віку значною мірою ґрунтується на теоріях психології (біхевіоризму, когнітивізму, когнітивного конструктивізму та психології розвитку), які розглядали процес навчання як феномен особистості. 
Водночас у площині соціокультурної психології, теорії активності і теорії пізнання наукові дослідження сформували розуміння навчальної діяльності як форми соціальної участі. Тобто, навчання (у різних формах) $€$ невід'ємним компонентом особистісного розвитку людей третього віку і механізмом соціальної взаємодії та суспільної інтеграції осіб цього вікового сегмента.

Дослідження у галузі освітньої геронтології доводять прямий зв'язок між рівнем освіченості громадян та їхніми потенційними можливостями й бажаннями продовжувати навчання у пізньому віці: «Чим вищий рівень освіти людини, тим більше вона ії потребує і $є$ більш активною в подальшій освітній діяльності» (Boulton-Lewis, 2010, р. 214). Вивчаючи мотивацію старших дорослих до навчальної діяльності, М. Вулф (M. Wolf) наголошував на важливості освіти осіб цієї вікової групи для цивілізаційного розвитку, оскільки це можливість людей бути корисним суспільству, долучитися до культурного поступу через набуті знання і досвід (Wolf, 2009).

Навчальну діяльність людини у пізньому зрілому віці пов'язують із якістю її життя. Зауважимо, що якість життя у цей період залежить від п'яти головних факторів: здоров'я, соціально-економічного статусу, віку, рівня активності та суспільної інтеграції (Merriam, Kee, 2014, р. 131). Два останні серед зазначених факторів пов'язані з навчальною діяльністю, оскільки вона - один з дієвих механізмів підтримання активності (ментальної, психічної, фрізичної) та соціальної інтеграції людей третього віку. Чим більш соціально активною, освіченою та здоровою (як у фрізичному, так і в психічному аспекті) $€$ людина у пізньому зрілому віці, тим менше навантаження лягає на її сім'ю та соціальні ресурси.

Соціальна інтеграція, залучення до суспільного життя осіб третього віку через продуктивну діяльність, волонтерську роботу, навчання (формальне, неформальне та інфрормальне) і змістовне дозвілля здійснюють позитивний вплив на ментальне й фрізичне здоров'я (Herzog, Ofstedal \& Weeler, 2002, p. 595). Крім того, дослідження доводять, що чим різноманітніші види діяльності людини, тим вища якість її життя, у порівнянні з тими, хто веде ізольований та одноманітний спосіб життя (Herzog, Ofstedal \& Weeler, 2002 , р.595). Відповідно, навчання фрактично стає головною ссрерою діяльності людей третього віку, через яку зреалізовується соціальна активність та інтеграція осіб цієї вікової групи, а відтак - підвищується якість їхнього життя.

Прагнення і мотивація людей третього віку до навчальної діяльності логічно вписується в епігенетичну теорію життєвого шляху особистості E. Еріксона (E. Erikson), який доводить, що розвиток особистості триває впродовж усього життя, і кожна психосоціальна стадія цього розвитку може мати і позитивний, і негативний ефект, який залежить від біологічних, психологічних та соціальних компонентів і базується на досягненнях чи втратах на попередніх стадіях. Е. Еріксон наголошує на біосоціальній природі та адаптивному характері поведінки особистості та вважає, що ії гармонійний розвиток значною мірою залежить від побудови відносин співробітництва людини й суспільства (S. Poole \& J. Snarey, 2011, p. 599; E.H. Erikson, J. M. Erikson, 1998). 
Для восьмого етапу зрілості особистості (за Е. Еріксоном) - «пізня зрілість» - характерний психосоціальний конфрлікт «цілісність-відчай». Відповідно на цьому етапі розвитку особистості, який припадає на постпенсійну фазу життя, відхід людини від соціально значущих ролей в суспільстві сприяє виникненню альтернативних шляхів розвитку особистості:

- позитивного, якщо людина інтегрується в суспільне життя, відчуває свою потрібність та корисність і, таким чином, підтримує свою емоційно-особистісну та пізнавальну сфреру;

- негативного, що відбувається у разі суспільної ізоляції, відсторонення, неадаптованості до швидкозмінних умов життя та особистісної деградації.

Людину в пізньому зрілому віці особливо турбує питання, чи було їі життя змістовним. На цьому етапі розвитку люди цінують життя в його історичному контексті. Тому особистість, яка має відчуття гармонійності й цілісності від власного внеску в суспільство, може розраховувати на позитивний напрям розвитку - его-цілісність (S. Poole, J. Snarey, 2011, p. 602). Незважаючи на суттєві фізіологічні та психічні зміни, які неминучі на цьому віковому етапі, людина, на переконання Е. Еріксона, повинна залишатися соціально активною особистістю, інтегрованою в суспільне життя. Натомість відчуття втрачених можливостей та беззмістовності прожитих років призводить до відчаю (Е. H. Erikson, J. M. Erikson, 1998). Очевидно, що освіта (навчання) у третьому віці дозволяє людям, набуваючи нових знань і досвіду, долучитися до розвитку культури й цивілізації загалом. За висновком ВООЗ, навчальна діяльність - вагомий чинник суспільної інтеграції осіб третього віку; крім того, вона позитивно впливає на підвищення якості їхнього життя (World Health Organization (WHO), 2002, p. 16).

Дослідження американської наукової організації Мак Артур (McArthur Study) довели, що залучення осіб похилого віку у змістовну та корисну діяльність має позитивний вплив на здоров'я, довголіття та задоволення життям, а також знижує ризик фізичних та психічних хвороб (R. Butler, 2002, р. 323). Таким чином, освіта у третьому віці виконує адаптивну функцію, оскільки сприяє пристосуванню людини до зміни способу життєдіяльності у технологічному, соціальному, фінансовому та здоров'язбережувальному аспектах. Саме адаптивна здатність людини та вміння вирішувати проблеми - головна умова активного довголіття (C. Smits, D. Deeg, B. Schmand, 1999). Навчання у третьому віці відіграє важливу інтегративну фуннкцію та сприяе позитивному напряму особистісного розвитку, тобто цілісності («integrity» за Е. Еріксоном).

Зауважимо, що позиції про ціложиттєвий особистісний розвиток дотримувалися А. Адлер, Б. Фромм, К. Хорні. Зокрема, американська дослідниця у сфрері психоаналізу, психіатрії та психології К. Хорні (K. Horney) довела домінуючий вплив соціального оточення та суспільства на розвиток особистості (К. Horney, 1950).

Перша психологічна теорія навчання була сформульована у площині біхевіоризму й акцентувала на можливості навчати, використовуючи біхевіоральні техніки, розбивати складні фрорми поведінки на сукупність 
простіших і винагороджувати за правильне виконання. Однак в освітньому процесі для осіб третього біхевіористична модель навчання не сприяє глибокому розумінню та концептуалізації знань, автономії суджень.

Модель навчання, основана на теорії когнітивізму, зміщує технологію навчальної діяльності від редукціонізму біхевіористського підходу до усвідомлення ментальної комплексності у процесі навчання. Ця модель зосереджує увагу радше на наявних знаннях і компетентностях слухачів, аніж на відтворенні інформації чи форм поведінки. Такий підхід є основним при організації освітнього процесу для людей третього віку, оскільки у них суттєвий соціальний та професійний досвід, який дозволяє застосовувати контекстний підхід у навчанні.

Теорія когнітивного конструктивізму наголошує на активній участі слухача в освітньому процесі, зокрема у виборі й створенні навчальних стратегій та автономності у формуванні траєкторії навчання.

Вивчення процесу особистісного розвитку людини у період пізньої зрілості дає розуміння принципів функціонування суспільства. Оскільки навчання пов'язане з процесом розвитку особистості, психологічні теорії розвитку є основним підґрунтям ціложиттєвої освіти, тому що розглядають людину в контексті її розвитку на всіх етапах життєвого циклу, але доводять, що на кожному етапі повинні використовуватися найбільш відповідні форми і методи навчання (Models of adult learning: a literature review, 2003, p. 10).

Деякі теорії розвитку Д. Левінсон, Е. Еріксон (D. Levinson, E. Erikson) зосереджують увагу на різних періодах, фазах, цілях та соціальних ролях людей на віковій стадії зрілості та пізньої зрілості і впливу цих факторів на процес їхнього навчання. Д. Левінсон запропонував теорію життєвого циклу, яка складається з чотирьох ер (приблизно по 25 років), для кожної з яких властивий певний характер і період розвитку (Levinson, 1986, p. 5-6).

Згідно з моделлю вікової періодизації Е. Еріксона, на кожному етапі життєвого циклу людини є «можливість для навчання» («teachable moment») (E. Erikson, 1982; E.H. Erikson, J. M. Erikson, 1986). Однак зазначені теорії меншою мірою враховують роль соціального і культурного контексту, у якому живе людина, і визначають фактично єдиний лінійний шлях розвитку для кожного індивіда. Натомість Б. Нейгартен (B. Neugarten) зазначає, що кожне суспільство має певні очікування щодо відповідної до віку поведінки, і вона радше соціально зумовлена, аніж самостійна (Neugarten, 1976). І якщо зміни поведінки, пов'язані з віком, не відповідають цим очікуванням, то вони вважаються проблемними.

К. Рейджел (K. Riegel) сфрормулював комплексне поняття людського розвитку, який охоплює чотири виміри: внутрішньо-біологічний, індивідуально-психологічний, культурно-психологічний та фрізичний (Riegel, 1976). Період їх збалансованості $є$ радше винятком, аніж правилом. Коли між двома чи більше напрямами особистісного розвитку відбувається конфолікт, з'являється потенціал для змін (Tennant \& Pogson, 1995). Тому розвиток $\epsilon$ нормальним постійним безперервним процесом, а навчальна діяльність невід'ємний компонент ціложиттєвого особистісного розвитку.

Психологи М. Теннант і П. Погсон (Tennant, Pogson, 1995), 
досліджуючи вплив навчальної діяльності на розвиток особистості у пізньому віці, дійшли висновку, що особистісний розвиток людей на етапі зрілості та пізньої зрілості (третього віку) відбувається на усіх етапах життєвого циклу. Тобто, фокус уваги необхідно змістити до соціальних і культурних процесів, які сприяють змінам та стимулюють розвиток особистості, а механізмом його реалізації $€$ також і навчання як один з видів соціальної активності людини у третьому віці. Головна ідея, яку обґрунтовують психологічні теорії розвитку, ціложиттєвий особистісний розвиток. У період зрілості та пізньої зрілості його потрібно розглядати не як окремий лінійний процес із заданими цілями, а як історично, соціально і культурно зумовлений процес. Тому, коли говоримо про навчальну діяльність у третьому віці, важливо знати, у які соціальні ролі, позиції та досвід залучена людина. Такий підхід дасть змогу ефективно організувати освітній процес і сприяти подальшому особистісному розвитку старших людей у бажаному для них напрямі.

Іншою важливою науковою платформою, на якій формувалися засади освіти людей третього віку, $€$ теорія активності та соціального конструктивізму (L. Vygotsky, J. Wertsch, J. Piaget, J. Bruner, A. Leont'ev, M. Cole, A. Luria та ін.). Представники теорії активності (соціокультурної теорії) зосередили увагу на вивченні ментальної сфери в контексті постійної, змістовної, цілеспрямованої взаємодії з іншими людьми, активованої семіотичними та матеріальними засобами. Зокрема, Л. Виготський довів, що розвиток вищого психічного функціонування індивіда залежить і від біофізичних процесів (від дозрівання мозку), і від соціальної взаємодії (Vygotsky, 1978). Вчений підтримував підхід соціального конструктивізму, 3 перспективи якого взаємодія з іншими людьми та культурними артефактами (не лише з новими ідеями) $€$ вирішальною для навчальної діяльності. Когнітивна стимуляція відбувається, насамперед, у соціальній площині, зокрема через соціальну взаємодію, і тільки тоді - у психологічному плані. Тобто, соціальна взаємодія лежить в основі розвитку усіх вищих когнітивних функцій (мислення, довільна увага, логічна пам'ять).

На відміну від Дж. Піаже (J. Piaget), який вважав, що розвиток має передувати навчанню (Piaget, 1970), Л. Виготський дотримувався думки, що розвиток особистості (зокрема, інтелектуальний) відбувається у процесі соціальних контактів з іншими людьми. Таке переконання вченого покладено в основу соціокультурної теорії розвитку вищих психічних функцій, яка певною мірою обґрунтовує навчання у пізньому зрілому віці як потребу соціальної взаємодії задля підтримання когнітивних функцій та особистісного розвитку, оскільки в освітній геронтології людину похилого віку вивчають 3 перспективи розвитку.

Теорія активності (А. Leont'ev, A. Luria, M. Cole, Y. Engestrom, O. Vasquez та ін.) розглядає навчання з точки зору систем діяльності спільнот людей, залучених у спільну діяльність. Вчені наголошують на значенні соціальної взаємодії та посередницьких артефактів у культурно організованій цілеспрямованій діяльності, якою вважають навчання. Тобто, в основі підходів до навчальної діяльності - не індивідуальне розуміння, а контекст (Cole, Engestrom, Vasquez, 1997; Leont'ev, 1978; Luria, 1976). 
Організація навчальної діяльності дорослих і старших дорослих значною мірою здійснюється через навчання на практиці. Ефективність такої форми довели психологи Д. Лейв (D. Lave) та Е. Венгер (E. Wenger). Ці ідеї лягли в основу теорії ситуативного навчання як альтернативи до інструктивного. Якщо у теоріях когнітивізму, згаданих вище, знання розглядають як абстрактну величину в ментальній сфері людини, то ситуативне навчання акцентує на ситуаціях та контексті, у яких відбувається освітній процес. Вчені розвинули поняття «навчання в процесі роботи» та фрактично обґрунтували принцип взаємного навчання у психологічному контексті (Lave, Wenger, 1991). Д. Лейв і Е. Венгер також стверджували, що кожний вид діяльності відбувається у певному ситуативному контексті та у певній культурі (Lave \& Wenger, 1991, p. 33). Навчальна діяльність $€$ невід'ємною складовою соціальної активності; вчені розглядають навчання радше як засіб, що допоможе людям долучитися до соціальної участі, а не спосіб набуття неконтекстуальних навичок. Відповідно до ситуативної моделі навчання, в освіті дорослих і старших дорослих важливо знайти той вид соціальної діяльності, в якій люди цієї вікової категорії хочуть чи потребують брати участь, та запропонувати можливості для навчання через залучення у таку діяльність. Що більш важливо, люди третього віку вже залучені в різноманітні форми соціальної діяльності у їхньому щоденному житті, тому опертя на цей досвід та його використання в навчанні осіб похилого віку $\epsilon$ вагомим фрактором їх мотивації до освітньої діяльності (Wenger, 1998). Е. Венгер запропонував концепт «спільнота практикуючих», визначаючи таку спільноту як групу осіб, які регулярно залучені в діяльність співтовариства, а навчання і викладання основуються на кооперації учасників освітнього процесу. Він показав, що навчання, як ситуативна соціальна практика, продовжується в діяльності спільноти, пояснюючи контекстуальне розуміння навчальної діяльності на противагу переважаючим неконтекстуальним когнітивним моделям. Обмін досвідом та інформацією - головна умова ефрективного навчання (Lave \& Wenger, 1991). Роль викладача, на погляд вчених, полягає не стільки в інструктажі та викладанні, як в організації соціальної взаємодії та структуруванні навчального матеріалу таким способом, щоб він був активно засвоєний. Цей підхід лежить в основі принципу взаємонавчання в організації освітнього процесу для осіб третього віку в Інститутах освіти впродовж життя (Lifelong Learning Institutes) та Інститутах навчання на пенсії (Learning in Retirement Institutes), які діють як структурні підрозділи закладів вищої освіти у США.

Таким чином, можемо виокремити дві контрастні групи моделей навчання людей третього віку у психології. Такі напрями у психологічній науці як біхевіоризм, когнітивізм та когнітивний конструктивізм розглядають навчальну діяльність у площині індивідуального розвитку особистості з точки зору зміни моделей поведінки чи розумової діяльності. Пізніше набула розвитку альтернативна ідея щодо навчання старших дорослих (осіб третього віку) в таких площинах як соціокультурна психологія, соціальний конструктивізм, теорія активності, ситуативне пізнання. Вона підтримується дослідженнями, які, відійшовши від експериментальної установки, вивчають 
процес навчання в контексті повсякденного життя людей і доводять, що навчання - це соціально-ситуативний френомен (Lane, 1988).

Зокрема, теорія соціального конструктивізму важливого значення надає самому процесові навчання та передумовам і засобам, за яких він відбувається. Г. Рейнман (G. Reinmann) і Г. Мандл (H. Mandl) визначили шість головних характеристик процесу навчання з погляду конструктивізму, а саме, навчання як:

- активний формувальний процес: знання можна здобути тільки через самостійну й активну участь у навчанні;

- конструктивний процес: знання можна здобути і втратити лише тоді, коли вони «вбудовані» в уже існуючі конструкції знань та інтерпретовані на основі досвіду індивіда;

- емоційний процес: для здобуття знань необхідно, щоб людина переживала позитивні емоції, натомість страх і стрес перешкоджають цьому;

- самокерований процес: важливо, щоб особа, яка здобуває знання, сама спрямовувала і контролювала його; людьми;

- соціальний процес, оскільки відбувається через взаємодію з іншими

- ситуативний процес, який пов'язаний 3 певним контекстом, ситуацією, навчальним середовищем, що $\epsilon$ необхідним для здобуття відповідних знань і компетентностей (Mandl, Kopp, 2005).

Соціокогнітивний підхід до навчальної діяльності базується на позиції, що соціальна взаємодія - важлива складова пізнання (Resnick, 1991). Усвідомлення, що процес пізнання різниться у кожної людини і чутливо реагує на культурний контекст, у якому він відбувається, формує основу для розуміння способів передачі людьми знань. Головним твердженням $€$ те, що пізнання - це активність, яка відбувається через соціальну взаємодію, та пов'язана з мотиваційною, емоційною і соціальною сорерами індивіда (Gruber, Law, Mandl, Renkl, 1995). Прихильники соціокогнітивного підходу вбачали основну проблему навчання у традиційно організованому освітньому процесі в його індивідуалізації та ізоляції: думка учня (слухача) зазвичай не отримує належної підтримки, студенти здобувають кваліфікації та досвід, які відірвані від реального життя та практично орієнтованого контексту. Тому навчальне середовище потрібно вибудувати у такій формі, де теорія і практика поєднані через соціальну взаємодію, що дасть змогу студентам набувати практичні компетентності і досвід у відповідному контексті.

Висновки і перспективи подальших досліджень. На підставі аналізу та порівняння підходів до навчання старших дорослих (осіб третього віку) в контексті основних напрямів психології, можемо визначити засади навчальної діяльності людей третього віку:

- люди третього віку мають власну (різну) мотивацію для освіти: позитивний особистісний розвиток, продовження професійної кар'єри, суспільна інтеграція;

- навчальна діяльність базується на раніше здобутих знаннях і 
компетентностях, життєвому та професійному досвіді індивіда;

- старші дорослі прагнуть самостійно організовувати освітній процес і мають для цього достатній рівень автономії і досвіду. Роль викладача зводиться до створення відповідного освітнього середовища та модерування навчального процесу;

- організація освітньої діяльності повинна здійснюватися 3 використанням різних стилів навчання, відповідно до можливостей і потреб людей третього віку;

- організація освітнього процесу для осіб третього віку базується на рефлексивному та експериментальному виді навчальної діяльності: від постановки проблеми і конкретного завдання до їх вирішення в реальних життєвих ситуаціях;

- рефлексивне навчання дає можливість індивіду «реорганізувати» свій попередній досвід і побачити ситуацію в новому світлі. Таким чином, навчання людей третього віку є потенційно трансформаційне і для індивіда, i для суспільства загалом.

Отже, навчальна діяльність - невід'ємна умова позитивного старіння в сучасному суспільстві з характерною тенденцією демографічного постаріння населення. Навчання сприяє підтриманню когнітивної здатності та розумової активності людей третього віку, підвищенню їх адаптивної функції та соціальної взаємодії. Потреба в суспільній інтеграції осіб третього віку випливає з необхідності адаптації до швидкозмінних умов життя, які охоплюють зміни в економічній, соціальній та культурній сферах суспільного розвитку. Навчання у третьому віці $\epsilon$ запорукою позитивного шляху особистісного розвитку, оскільки уможливлює інтеграцію індивіда в суспільне життя. Людина, будучи соціально активною у період пізньої зрілості, відчуває свою потрібність та корисність і в такий спосіб підтримує свою емоційноособистісну та пізнавальну сферу.

\section{Список використаних джерел}

Аніщенко, О., Лук'янова, Л. \& Прийма, С. (2017). Неформальна освіта дорослих - освітній тренд XXI століття. Рідна школа, 11-12, 3-8.

Баніт, О. (2016). Філософські витоки розвитку особистості в системі неперервної освіти. Андрагогічний вісник, 7, 45-52.

Коваленко, О.Г. (2015). Міжособистісне спілкування осіб похилого віку : психологічні аспекти: монографрія. Київ: Інститут обдарованої дитини, 256.

Лук'янова, Л.Б. (2018). Освітні потреби різних категорій дорослих у контексті особистісного і професійного розвитку. Профресійна освіта: андрагогічний підхід : монографрія / кол. авторів; за ред. О. А. Дубасенюк. Житомир: Вид. О.О. Євенок, 42-67.

Чаграк, Н.І. (2018). Освіта людей похилого віку в контексті концепції успішного старіння. Наукові записки Тернопільського національного педагогічного університету імені Володимира Гнатюка. Серія Педагогіка, 1, 148-157.

Bass, S. A. (1986). Matching educational opportunities with the able elderly. 
Lifelong Learning, 9 (5), 4-7.

Boulton-Lewis, G.M. (2010). Education and Learning for the Elderly: Why, How, What. Educational Gerontology, 36, 213-228.

Brady, M. (1983). Personal growth and the Elderhostel experience. Lifelong Learning, 3 (6), 11-13.

Butler, R.N. (2002). The study of productive aging. The Journals of Gerontology: Series B: Psychological Sciences as Sciences, 57(6), 323.

Cole, M., Engestrom, Y., \& Vasquez, O., Eds. (1997). Mind, Culture and Activity: Seminal Papers from the Laboratory of Comparative Human Cognition. Cambridge: Cambridge University Press.

Cole, W. \& Harris, D. (1977). The elderly in America. Boston: Allyn \& Bacon. Cross, K.P. (1981). Adults as learners. San-Francesco, CA: Jossey-Bass.

Erikson, E.H. \& Erikson, J.M. (1998). The Life Cycle Completed (Extended Version with New Chapters on the Ninth Stage of Development by Joan M. Erikson). New York: WW Norton and Company.

Glendenning, F. (2001). Education for older adults. International Journal of Lifelong Education, 20 (1), 63-70.

Groombridge, B. (1982). Learning, education and later life. Adult Education, 54 (4), 314-325.

Gruber, H., Law, L.-C., Mandl, H. \& Renkl, A. (1995). Situated learning and transfer. Learning in humans and machines: Towards an interdisciplinary learning science. P. Reimann, H. Spada (Eds.). Oxford: Pergamon, 139156.

Harrison, R. (1993). Learning later five years on. Adults Learning, 5, 4, 94-95.

Havighurst, R.J. (1972). Developmental tasks and education. (3rd ed.). New York: David McKay.

Herzog, A. R., Ofstedal, M.B., \& Wheeler, L.M. (2002). Social engagement and its relationship to health. Clinics in Geriatric Medicine, 18, 595-609.

Hiemstra, R.P. (1975). The older adult and learning. Lincoln, NE: University of Nebraska.

Hiemstra, R.P. (1976). The older adult's learning projects. Educational Gerontology, 1, 331-341.

Horney, K. (1950). Neurosis and Human Growth. Norton, New York.

James, D., Gibson, F., McAuley, G. \& McAuley, J. (1996). Introducing older learners to information technology through life history writing. International Journal of Lifelong Education, 15 (1), 50-58.

Jarvis, P. (1980). Pre-retirement education: Design and analysis. Adult Education, 53(1), 14-19.

Keith, J. (1982). Old People as People. Social and Cultural Influences on Ageing and Old Age. Boston;Toronto: Little, Brown and Company.

Knowles, M. (1980). The Modern Practice of Adult Education: Andragogy versus Pedagogy. Revised and updated edition. Chicago: Follet Publishing Company.

Lane, J. (1988). Cognition in Practice: Mind, Mathematics and Culture in Everyday Life. Cambridge: Cambridge University Press.

Laslett, P.A. (1991). Fresh Map of Life: The Emergence of the Third Age. 
Cambridge, MA: Harvard University Press.

Lave, J. \& Wenger E. Situated Learning: Legitimate Peripheral Participation. Cambridge: Cambridge University Press.

Leont'ev, A.N. (1978). Activity, consciousness, and personality. Englewood Cliffs and London: Prentice Hall.

Levinson, D.J. (1986). A Conception of Adult Development. American Psychologist, 41 (1), 3-13.

Luria, A.R. (1976). Cognitive Development, its Cultural and Social Foundations. M. Cole, Ed. Cambridge, MA and London: Harvard University Press.

Mandl, H. \& Kopp, B. (2005). Situated Learning: Theories and Models. P. Nentwig, D. Waddington (Eds.). Making it relevant. Context based learning of science. Munster: Waxmann.

McClusky, H. (1973). Education. Towards a national policy on aging (Final report, 2, 1971. White House Conference on Aging). Washington, DC: Government Printing Office.

Merriam, S.B., Caffarrella, R.S., \& Baumgartner, L. (2007). Learning in adulthood (3rd ed.). San-Francisco, CA: Jossey-Bass.

Merriam, S.B. \& Kee, Y. (2014). Promoting Community Wellbeing: The Case for Lifelong Learning for Older Adults. Adult Education Quarterly, 64 (2).128-144.

Models of adult learning: a literature review (2003). Tusting Karin \& Barton David. Leicester: National Research and Development Centre for Adult Literacy and Numeracy.

Neugarten, B. (1976). Adaptation and the life cycle. American Journal of Psychiatry, 136, 887-893.

Peterson, D.A. (1985). A history of education for older learners / D.B. Lumsden. The Older Adult as Learner: Aspects of Educational Gerontology. New York; NY: Hemisphere.

Piaget, J. (1970). The Science of Education and the Psychology of the Child. New York: Grossman.

Poole, S. \& Snarey, J. (2011). Erikson's stages of the life cycle. S. Goldstein, J. Noglieri (Eds.) Encyclopedia of Child Behaviour and Development, 2, 599-603. New York: Springer.

Resnick, L. B. (1991). Shared cognition: Thinking as social practice. L. Resnick, J. Levine, and S. Teasley (Eds.). Perspectives on socially shared cognition. Washington, DC: American Psychological Association.

Riegel, K. (1976). The dialectics of human development. American Psychologis, 31, 689-700.

Shea, P. \& Tidmarsh, M. (1981). An Anglo-French summer school for elders. Adult Education, 53 (6), 367-371.

Smits, C.H., Deeg, D.M., \& Schmand, B. (1999). Cognitive functioning and health as determinants of mortality in older populations. American Journal of Epidemiology, 150(9), 978-986.

Tennant, M. \& Pogson, P. (1995). Learning and Change in Adult Years: A Developmental Perspective. - San Francisco: Jossey-Bass.

Thorndike, E, Bregman, E., Tilton, J., \& Woodyard E. (1928). Adult learning. New 
York: Macmillan.

Townshend, I. (1996). An Urban Geography of the Third Age: Canadian Metropolitan Segregation and Community Cohesion in Calgary. Calgary, Alberta.

Treybig, D. (1974). Language, children and attitudes toward the aged: A longitudinal study. Gerontologist, 14(5).

Vygotsky, L.S. (1978). Mind in Society. Cambridge, MA: Harvard University Press.

Wenger, E. (1998). Communities of Practice: Learning, Meaning and Identity. Cambridge: Cambridge University Press.

Wolf, M.A. (2009). Older adulthood. P. Jarvis (Ed.). The Routledge international handbook of lifelong learning. London: Routledge.

World Health Organization (WHO). (2002). Active ageing: A policy framework. URL: http://who.int/hpr/ageing/ActiveAgeingPolicyFrame.pdf

\section{References (translated and transliterated)}

Anishchenko, O., Lukianova, L. \& Pryima, S. (2017). Neformalna osvita doroslykh osvitnii trend XXI stolittia [Non-formal adult education is an educational trend of the XXI century]. Ridna shkola - Native school, 11-12, 3-8 [in Ukrainian].

Banit, O. (2016). Filosofski vytoky rozvytku osobystosti v systemi neperervnoi osvity [Philosophical origins of personality development in the system of continuing education]. Andrahohichnyi visnyk - Andragogical Bulletin, 7, 45-52 [in Ukrainian].

Kovalenko, O. (2015). Mizhosobystisne spilkuvannia osib pokhyloho viku: psykholohichni aspekty [Interpersonal communication of the elderly: psychological aspects]: monohrafiia. Kyiv: Instytut obdarovanoi dytyny, 256 [in Ukrainian].

Lukianova, L.B. (2018). Osvitni potreby riznykh katehorii doroslykh u konteksti osobystisnoho i profesiinoho rozvytku. Profesiina osvita: andrahohichnyi pidkhid [Educational needs of different categories of adults in the context of personal and professional development. Vocational education: an andragogic approach]: monohrafiia / O.A. Dubaseniuk (Ed.). Zhytomyr, 42-67 [in Ukrainian].

Chahrak, N.I. (2018). Osvita liudei pokhyloho viku v konteksti kontseptsii uspishnoho starinnia [Elderly education in the context of the concept of successful aging]. Naukovi zapysky Ternopilskoho natsionalnoho pedahohichnoho universytetu imeni Volodymyra Hnatiuka. Seriia Pedahohika, 1, 148-157 [in Ukrainian].

Bass, S.A. (1986). Matching educational opportunities with the able elderly. Lifelong Learning, 9(5), 4-7 [In English].

Boulton-Lewis, G.M. (2010). Education and Learning for the Elderly: Why, How, What. Educational Gerontology, 36, 213-228 [In English].

Brady, M. (1983). Personal growth and the Elderhostel experience. Lifelong Learning, 3(6), 11-13 [In English].

Butler, R.N. (2002). The study of productive aging. The Journals of Gerontology: Series B: Psychological Sciences as Sciences, 57(6), 323 [In English].

Cole, M., Engestrom, Y., \& Vasquez, O., Eds. (1997). Mind, Culture and Activity: Seminal Papers from the Laboratory of Comparative Human Cognition. Cambridge: Cambridge University Press [In English].

Cole, W. \& Harris, D. (1977). The elderly in America. Boston: Allyn \& Bacon [In English]. 
Cross, K.P. (1981). Adults as learners. San-Francesco, CA: Jossey-Bass [In English].

Erikson, E.H. \& Erikson, J.M. (1998). The Life Cycle Completed (Extended Version with New Chapters on the Ninth Stage of Development by Joan M. Erikson). New York: WW Norton and Company [In English].

Glendenning, F. (2001). Education for older adults. International Journal of Lifelong Education, 20(1), 63-70 [In English].

Groombridge, B. (1982). Learning, education and later life. Adult Education, 54(4), 314-325 [In English].

Gruber, H., Law, L.-C., Mandl, H. \& Renkl, A. (1995). Situated learning and transfer. Learning in humans and machines: Towards an interdisciplinary learning science. P. Reimann, H. Spada (Eds.). Oxford: Pergamon, 139-156 [In English].

Harrison, R. (1993). Learning later five years on. Adults Learning, 5, 4, 94-95 [In English].

Havighurst, R.J. (1972). Developmental tasks and education. (3rd ed.). New York: David McKay [In English].

Herzog, A.R., Ofstedal, M.B., \& Wheeler, L.M. (2002). Social engagement and its relationship to health. Clinics in Geriatric Medicine, 18, 595-609 [In English].

Hiemstra, R.P. (1975). The older adult and learning. Lincoln, NE: University of Nebraska [In English].

Hiemstra, R.P. (1976). The older adult's learning projects. Educational Gerontology, 1, 331-341 [In English].

Horney, K. (1950). Neurosis and Human Growth. Norton, New York [In English].

James, D., Gibson, F., McAuley, G. \& McAuley, J. (1996). Introducing older learners to information technology through life history writing. International Journal of Lifelong Education, 15(1). P. 50 - 58 [In English].

Jarvis, P. (1980). Pre-retirement education: Design and analysis. Adult Education, 53(1), 14 - 19 [In English].

Keith, J. (1982). Old People as People. Social and Cultural Influences on Ageing and Old Age. Boston - Toronto: Little, Brown and Company [In English].

Knowles, M. (1980). The Modern Practice of Adult Education: Andragogy versus Pedagogy. Revised and updated edition. Chicago: Follet Publishing Company [In English].

Lane, J. (1988). Cognition in Practice: Mind, Mathematics and Culture in Everyday Life. Cambridge: Cambridge University Press [In English].

Laslett, P.A. (1991). Fresh Map of Life: The Emergence of the Third Age. Cambridge, MA: Harvard University Press [In English].

Lave, J. \& Wenger, E. Situated Learning: Legitimate Peripheral Participation. Cambridge: Cambridge University Press [In English].

Leont'ev, A.N. (1978). Activity, consciousness, and personality. Englewood Cliffs and London: Prentice Hall [In English].

Levinson, D.J. (1986). A Conception of Adult Development. American Psychologist, 41(1), 3-13 [In English].

Luria, A.R. (1976). Cognitive Development, its Cultural and Social Foundations. M. Cole, Ed. Cambridge, MA and London: Harvard University Press [In English].

Mandl, H. \& Kopp, B. (2005). Situated Learning: Theories and Models. P. Nentwig, D. Waddington (Eds.). Making it relevant. Context based learning of science. Munster: Waxmann [In English].

McClusky, H. (1973). Education. Towards a national policy on aging (Final report, Vol. 2, 1971 White House Conference on Aging). Washington, DC: Government 
Printing Office [In English].

Merriam, S.B., Caffarrella, R.S., \& Baumgartner, L. (2007). Learning in adulthood (3rd ed.). San-Francisco, CA: Jossey-Bass [In English].

Merriam, S.B. \& Kee, Y. (2014). Promoting Community Wellbeing: The Case for Lifelong Learning for Older Adults. Adult Education Quarterly, 64(2).128-144 [In English].

Models of adult learning: a literature review (2003). Tusting Karin \& Barton David. Leicester: National Research and Development Centre for Adult Literacy and Numeracy [In English].

Neugarten, B. (1976). Adaptation and the life cycle. American Journal of Psychiatry, 136, 887-893 [In English].

Peterson, D.A. (1985). A history of education for older learners / D.B. Lumsden. The Older Adult as Learner: Aspects of Educational Gerontology. New York; NY: Hemisphere [In English].

Piaget, J. (1970). The Science of Education and the Psychology of the Child. New York: Grossman [In English].

Poole, S. \& Snarey, J. (2011). Erikson's stages of the life cycle. S. Goldstein, J. Noglieri (Eds.) Encyclopedia of Child Behaviour and Development, 2, 599603. New York: Springer [In English].

Resnick, L.B. (1991). Shared cognition: Thinking as social practice. L. Resnick, J. Levine, and S. Teasley (Eds.). Perspectives on socially shared cognition. Washington, DC: American Psychological Association [In English].

Riegel, K. (1976). The dialectics of human development. American Psychologis, 31, 689-700 [In English].

Shea, P. \& Tidmarsh, M. (1981). An Anglo-French summer school for elders. Adult Education, 53 (6), 367-371 [In English].

Smits, C.H., Deeg, D.M., \& Schmand, B. (1999). Cognitive functioning and health as determinants of mortality in older populations. American Journal of Epidemiology, 150(9), 978-986 [In English].

Tennant, M. \& Pogson, P. (1995). Learning and Change in Adult Years: A Developmental Perspective. - San Francisco: Jossey-Bass [In English].

Thorndike, E, Bregman, E., Tilton, J., \& Woodyard, E. (1928). Adult learning. New York: Macmillan [In English].

Townshend, I. (1996). An Urban Geography of the Third Age: Canadian Metropolitan Segregation and Community Cohesion in Calgary. Calgary, Alberta [In English].

Treybig, D. (1974). Language, children and attitudes toward the aged: A longitudinal study. Gerontologist, 14(5) [In English].

Vygotsky, L.S. (1978). Mind in Society. Cambridge, MA: Harvard University Press [In English].

Wenger, E. (1998). Communities of Practice: Learning, Meaning and Identity. Cambridge: Cambridge University Press [In English].

Wolf, M.A. (2009). Older adulthood. P. Jarvis (Ed.). The Routledge international handbook of lifelong learning. London: Routledge [In English].

World Health Organization (WHO). (2002). Active ageing: A policy framework. URL: http://who.int/hpr/ageing/ActiveAgeingPolicyFrame.pdf [In English]. 